Portland State University

PDXScholar

\title{
Understanding the Contribution of Curb Appeal to Retail Real Estate Values
}

\author{
Julia Freybote \\ Portland State University, jfreybote@gmail.com \\ Lauren Simon \\ Portland State University \\ Lauren Beitelspacher \\ Portland State University
}

Follow this and additional works at: https://pdxscholar.library.pdx.edu/busadmin_fac

Part of the Real Estate Commons

Let us know how access to this document benefits you.

\section{Citation Details}

Freybote, J., Simon, L., \& Beitelspacher, L. (2016). Understanding the contribution of curb appeal to retail real estate values. Journal of Property Research, 1-15.

This Post-Print is brought to you for free and open access. It has been accepted for inclusion in Business Faculty Publications and Presentations by an authorized administrator of PDXScholar. Please contact us if we can make this document more accessible: pdxscholar@pdx.edu. 


\title{
Understanding the Contribution of Curb Appeal to Retail Real \\ Estate Values
}

\author{
By \\ Julia Freybote*, Lauren Simon* and Lauren Beitelspacher*
}

\begin{abstract}
The concept of curb appeal and its impact on property values has been largely neglected in the real estate literature. In the context of retail real estate, curb appeal represents the general attractiveness of a store viewed from the sidewalk or parking lot that is expected to affect consumer patronage decisions and consequently property values. We develop a measurement instrument for curb appeal and assess the validity of our measure using exploratory and confirmatory factor analysis. Our results suggest that curb appeal is multi-dimensional and consists of an atmospheric, architectural and authenticity dimension. Using transaction data and a spatial autoregressive model, we find that the atmospheric and architectural component have a positive impact on sales prices of restaurants. We also show that curb appeal dimensions are highly correlated with observable building features traditionally included in hedonic pricing models.
\end{abstract}

\section{Keywords: Curb Appeal, Retail Real Estate, Hedonic Pricing Model, Spatial}

\section{Autoregression}

* School of Business Administration, Portland State University, Portland, Oregon 97207; Corresponding author: freybote@ pdx.edu; 503-725-3727 


\section{Introduction}

Customers have been found to base their purchase and patronage decisions on cues about a retailer (Baker, Grewal and Parasuraman, 1994). One of these cues is the external or curb appeal of a retail store. For the purpose of this paper, we define curb appeal as the attractiveness of retail store as viewed from the sidewalk or parking lot that will likely lead to the customer visiting the retailer.

While curb appeal is an important concept to retailers, real estate developers and brokers, it has been largely neglected in the real estate literature. One challenge of investigating curb appeal and its impact on asset pricing is that curb appeal is difficult to measure. As a consequence, the purpose of this study is two-fold. First, we develop a survey instrument to measure the multi-dimensional concept of curb appeal. Second, we quantify the contribution of curb appeal to the prices of retail-hospitality properties (restaurants).

In our empirical investigation, we focus on retail real estate as this segment of the real estate industry has experienced significant changes over the last decade, for example, with regard to the emergence of e-commerce and an increased emphasis on the lifestyle aspect of shopping. As a consequence, the need for developers and retailers to improve the appeal of retail facilities to consumers and influence their store patronage decisions has increased even more. While our findings are also relevant to developers specializing in other commercial real estate segments, they have particular implications for retail developers, investors and retailers. 
Our findings suggest that curb appeal is comprised of three dimensions, namely architecture, atmosphere and authenticity. Using transaction data and a spatial autoregressive model, we find that curb appeal overall positively affects sales prices. However, we find that only the architectural and atmospheric dimensions have a significantly positive impact on restaurant prices. The authenticity dimension of curb appeal has no impact.

Our study contributes to the real estate literature in a number of ways. Except for Seiler, Madhavan and Liechty (2012) and Vandell and Lane (1989), curb appeal has been neglected in the real estate literature. We develop an instrument to measure curb appeal, which can, with modifications, be applied to a variety of different property types and may represent the starting point for future studies on the impact of curb appeal on, for example, consumer behavior, employee behavior, rental rates and vacancies.

Our study complements Vandell and Lane (1989), who find a positive impact of architectural quality on office rental rates. We broaden the curb appeal definition by also including an atmospheric and authenticity dimension and quantifying the impact of each curb appeal dimension on sales prices. Hereby, we contribute to the hedonic pricing model literature, which has largely ignored curb appeal as an explanatory variable. Bajari et al. (2010) argue that if unobservable and commonly omitted attributes such as curb appeal are related to observable attributes commonly included in hedonic pricing models, OLS estimates are likely to be biased. The study in hand closes this gap in the hedonic pricing literature by providing insights into the effect of individual curb appeal dimensions on retail 
real estate prices, as well as the correlation of curb appeal dimensions with other observable predictors commonly included in hedonic pricing models.

The remainder of this paper is structured as follows. Next, we discuss the existing literature relevant to the development of our curb appeal measurement instrument as well as the data collection to derive our curb appeal measure. It is followed by a discussion of our hedonic pricing methodology and data, which is followed by the presentation of our results. Lastly, we present implications and a conclusion.

\section{Measuring Curb Appeal}

\section{Instrument Development}

An extensive literature in marketing and retailing has investigated retail store atmospherics, which relates to the architectural attractiveness of the store interior and the atmosphere created. Baker, Levy and Grewal (1992) show that the store environment (e.g. music and lighting) increases the pleasure of customers and purchasing behavior. It is beyond the scope of this paper to review the extensive literature on atmospherics in the retail setting, however, the main conclusion of this stream of literature is that physical features of a store, such as lighting or color, affect the emotional state of customers and their behavior (e.g. Grewal et al., 2003; Mattila and Wirtz, 2001; Turley and Milliman, 2000; Baker, Grewal and Parasuraman, 1994; Baker, Levy and Grewal, 1992; Grossbart et al., 1990). As a consequence, the attractiveness of a store has a high correlation with patronage decisions. 
While previous findings of studies on atmospherics focus on the interior of a store, we expect the exterior appearance of a store to also have a positive impact on consumer behavior, retailer sales and consequently retail real estate values. This expectation is in line with Vandell and Lane (1989), who find that the architectural quality of an office building has a positive impact on rental rates.

In addition to reviewing previous studies, we conduct a number of interviews with retail developers and brokers in Portland, Oregon to develop our curb appeal measurement instrument. These interviews yielded key words such as "cleanliness and maintenance", "social component", "landscaping", "entertainment", "convenience" and "authenticity" used by retail real estate experts to describe a good curb appeal of retail facilities. The importance of landscaping on curb appeal and in turn property values is in line with Donovan and Butry (2010) who find that trees increase the value of single-family homes. The social component of curb appeal mentioned by our expert panel is in line with previous findings in the marketing literature that social cues within the store environment also affect customers (Baker, Grewal and Parasuraman, 1994; Baker, Levy and Grewal, 1992).

Based on our interviews with retail real estate experts, we develop a survey instrument to measure the different components of curb appeal of retailhospitality properties (restaurants). Our survey instrument is presented in Table 1. Initially, we distinguish four dimensions of curb appeal, namely 1) cleanliness, safety and maintenance; 2) social aspects; 3) signage and architectural features as 
well as 4) authenticity. The measurement instrument was subsequently reviewed by another set of real estate expert for the purpose of fine-tuning.

\section{[Insert Table 1]}

To measure curb appeal and investigate its impact on sales prices, we obtained transaction data and photographs for restaurants sold in Los Angeles, CA MSA and San Diego, California MSA over the period of 1989 to 2014. The initial sample covers 1,194 transactions without any sales condition, non-arm-length or restaurants included in bulk or multi-property sales. We focus on restaurants (hospitality-retail) as opposed to non-food retail stores (leisure or convenience) to avoid any confounding effects of the attitude of survey respondents towards particular retailers and their brands. In line with this rationale, we also exclude any branded restaurants and chain restaurants from our sample.

Next, we eliminate all transactions without sales price information. For the empirical analysis, we only include sold restaurants for which we can obtain frontal view photos of the main entrance taken at curb appeal level. We furthermore only include stand-alone buildings and eliminate restaurants as part of a shopping center from the sample to avoid any confounding effects of surrounding buildings. Photos of restaurants in our sample were all taken while the restaurant was in operation. Transactions with photos containing a "for sale" or "for lease" sign were eliminated. 
Our rationale for using restaurants in Los Angeles and San Diego is the high availability of property pictures taken on sunny days. We only include properties with profile pictures taken on a sunny day in our sample to avoid any confounding effects of weather on curb appeal. A few transactions contained pictures that showed the subject property in different development stages, such as before and after a redevelopment. As it was not clear which picture represents the building at the time of sale, we eliminated these transactions from our sample. Our final sample comprises of 189 restaurant transactions in Los Angeles and San Diego.

As a next step, we combine our survey instrument with the sample photos and, after piloting the instrument with student subjects at a major Northwestern university, distribute it to a pool of anonymous Mechanical Turk (MTURK) users. Each respondent is asked to rate three different restaurants, which were randomly selected from a pool of 189 photos. No respondent rated the same photo twice. For each restaurant, we ask survey respondents to rate each of the items in Table 1, based on the photo shown, on a Likert scale of 1 to 5 with 1 strongly disagree and 5 strongly agree. MTURK respondents were based in the US, were required to have a Master level, which represents an elite group of MTURK workers, and were compensated with $\$ 0.75$ per survey. Each restaurant in our sample was rated by at least three different survey respondents. Overall, we received 909 different evaluations for individual restaurants. 


\section{Measurement Instrument Validation}

As part of the measurement validation process, it is valuable in the early phases of scale development to conduct exploratory factor analysis (EFA; Kelloway, 1995). EFA is a statistical data reduction procedure that provides insight into the dimensionality of a measure by identifying the manner in which items cluster together. Such analysis allows for a more parsimonious presentation of the data. An EFA was conducted for the pilot data, based on student subject responses, with oblique (Geomin) rotation using Mplus version 7.11 (Muthén and Muthén, 1998-2013). Oblique rotation accounts for the fact that identified factors, or dimensions, could be correlated with one another, rather than being completely orthogonal. Given that each photograph was assessed by multiple raters, we also accounted for the nested structure of the data using the Type = Complex command in Mplus, which adjusts for the lack of independence among individual observations when estimating standard errors (Muthén and Muthén, 1998-2013).

Based on several criteria such as the interpretability of factors, item crossloadings on more than one factor, drops in the scree plot, and minimum Eigen values (Ford, MacCallum and Tait, 1986), a three factor solution, consisting of 18 items was retained, which adequately fit the data (for more information, see Bentler, 1990; Browne and Cudeck, 1993; Hu and Bentler, 1999; Jöreskog and Sörbom, 1996). All factor loadings were statistically significant on their respective factor, and were above 0.5 . 
Table 1 presents an overview of survey items and the respective curb appeal dimensions based on the EFA. The first factor or dimension of curb appeal consists of 9 items that were indicative of a welcoming atmosphere, in terms of sociability, safety, and cleanliness (e.g., "appears to be in a safe and secure area," "has a clean appearance," and "seem like a great place for people to get together"). This dimension captures the atmospheric attributes of a restaurant $(C A A U T H)$. The second factor (5 items) focused more on the physical features of the restaurant, such as architecture and quality of construction (e.g., "is stylishly designed," "is located in a building made of high quality material") and captures the architectural dimension of curb appeal $(C A A R C H)$. The final factor (4 items) consisted of items that captured whether a restaurant seemed authentic or unique (e.g., "doesn't have a fake or plastic appearance") and consequently represents the authenticity dimension of curb appeal $(C A A U T H)$. All factors surpassed reliability standards (Cronbach's $\alpha=.70$ ) for newly developed scales (Nunnally, 1978), with the aforementioned factors exhibiting Cronbach's $\alpha$ 's of $.93, .89$, and .90 respectively. Consistent with prevailing guidelines, one item ("has appealing exterior signage") was removed from the original scale because it did not significantly load onto any of the factors.

Beyond conducting an EFA with the pilot sample, we conducted Confirmatory Factor Analyses (CFA) with the sample from the main study to ensure the factor structure identified in the EFA would replicate across samples. In contrast to EFA, CFA requires the researcher to specify the number of factors and to designate items to load onto particular factors beforehand, allowing for 
objective of testing of whether the data fits the hypothesized measurement model. Consistent with the results from the pilot sample, a three factor solution adequately fit the data and Cronbach's alpha reliabilities exceeded standards of acceptability (Factor 1, $\alpha=.93$; Factor 2, $\alpha=.94$; Factor 3, $\alpha=.87$ ), providing further evidence for the construct validity of our curb appeal measure. Thus, the three curb appeal dimensions as shown in Table 1 were retained in our hedonic pricing modeling, as discussed in the next section.

\section{Hedonic Pricing Model}

\section{Data and Methodology}

To assess the impact of curb appeal on restaurant prices, we derive average scores for each of the three curb appeal dimensions for each restaurant in the sample, based on the results of the EFA/CFA and the main survey responses. The resulting variables to be included in the empirical analysis are CAATM, which represents the atmospheric dimension, $C A A R C H$, which represents the architectural dimension and CAAUTH, which represents the authenticity dimension of curb appeal. The sum of each of these dimensions, CATOT, represents that overall curb appeal of a restaurant.

As control variables, we include age and its quadratic term, building size in square feet and land size in acre in our model. To control for general macroeconomic conditions, we furthermore include the annual unemployment rate for the State of California, the risk free interest rate based on the annual yield of a 3month treasury bill, reflecting inflation and real interest rate, and the return on the S\&P500 index as a proxy for overall economic conditions. An alternative control 
variable for macro-economic conditions is the GDP for the State of California. However, GDP information is only available until the end of 2013, which eliminates 15 restaurants sold in 2014 from our sample. As a consequence, we include the Californian GDP in a robustness check to be discussed in the results section.

Descriptive statistics for all variables included in the model are presented in Table 2. The average rating for the architectural dimension of curb appeal is the lowest compared to the atmosphere and authenticity dimensions. The variability on the architectural dimension is also the highest, which may be the result of a variety of architectural styles in our sample or the preference of survey respondents for certain architectural styles. Descriptive statistics suggest that building size and land area have outliers. To assess the impact of these five outliers on our results we remove them from our GS2SLS regression, however our results remain robust suggesting that the inclusion of these observations does not affect our results.

\section{[Insert Table 2]}

Table 3 presents the correlations of curb appeal variables with the dependent variable (Panel A) and observable independent variables (Panel B). Curb appeal has a significantly positive correlation with sales prices, which appears to be driven by the architectural and atmospheric dimensions of curb appeal. The authenticity dimension of a restaurant's curb appeal has no significant correlation with sales prices. The curb appeal dimensions have relatively high correlations 
amongst themselves, with the atmospheric and architectural dimensions being the most correlated.

As shown in Panel B, curb appeal also is significantly correlated with observable attributes of buildings commonly included in hedonic pricing models. The atmospheric dimension of curb appeal is significantly negatively correlated with a restaurant's age, which may be explained with superior maintenance and landscaping at newer restaurants. On the other hand, the authenticity dimension has a significantly positive yet small correlation with age, which suggests that older buildings are considered to be more authentic compared to newer buildings to some extent. Land area and building size are significantly positively correlated with the atmospheric and architectural dimensions of curb appeal. This may result from the fact that restaurants with more land area are more likely to have more outdoor seating and landscaping. The significant correlation of curb appeal dimensions with observable building attributes commonly included in hedonic pricing models supports the concern by Bajari et al. (2010) that if unobservable variables such as curb appeal, which are correlated with observable predictors, are omitted, OLS estimates are likely to be biased.

\section{[Insert Table 3]}


Following the existing literature, we employ a hedonic pricing model to assess the impact of curb appeal on restaurant sales prices. In our analysis, we account for the spatial correlation of observations and residuals, which has been found to be a particular importance to real estate transaction data (e.g. Clauretie and Daneshvary, 2009; Basu and Thibodeau, 1998; Dubin, 1998). As this spatial interdependence of observations and residuals violates ordinary least square (OLS) assumptions (Pace, Barry and Sirmans, 1998), we employ a spatial autoregressive model (Conway et al., 2008; Pace, Barry and Sirmans, 1998). In particular, we follow Kelejian and Prucha (1998) and employ a generalized spatial two stage least square (GS2SLS) model as shown in Equation 1 (for an in-depth discussion of the GS2SLS methodology, see Kelejian and Prucha, 1998). Autoregressive models extract information from spatially close transactions, which also addresses endogeneity problems due to omitted variables and reduces data collection requirements (Freybote, Sun and Yang, 2014; Sun, Tu and Yu, 2005).

$$
\begin{aligned}
& \log S P_{n}=X_{n} \beta+\lambda W_{n} \overline{\log S P}_{n}+u_{n}, \\
& u_{n}=\rho W_{n} \bar{u}_{n}+\varepsilon_{n}
\end{aligned}
$$

Where $\log S P_{n}$ is the $\log$ of sales prices for the $\mathrm{n} \times 1$ vector of observations, $X_{n}$ is the $\mathrm{n} \times 1$ matrix of observations for variables including curb appeal, $\beta$ is the $\mathrm{k} \times 1$ vector of regression parameters, $W_{n}$ is a $n \times n$ spatially weighted matrix of known constants, $\overline{\log S P_{n}}$ is the spatially lagged price of spatially close restaurants, $\bar{u}_{n}$ is the spatial lag of $u_{n}, \lambda$ and $\rho$ are autoregressive parameters, $u_{n}$ is the $\mathrm{n} \times 1$ vector of 
regression disturbances and $\varepsilon$ is a $\mathrm{n} \times 1$ vector of independent and identically distributed disturbances.

The spatially weighted matrix used is an inverse distance matrix, which relies on the $\mathrm{X}$ and $\mathrm{Y}$ coordinates of restaurants in the respective sample to generate a distance-weighted matrix to be used in our GS2SLS regression.

\section{Results}

The results of our GS2SLS regression are presented in Table 4. As curb appeal dimensions are highly correlated and introduce multi-collinearity, which makes the interpretation of coefficients difficult, we run our model for curb appeal overall as well as each dimension separately. Curb appeal overall (CATOT) has a significantly positive effect on sales prices. This effect is driven by the atmospheric $(C A A T M)$ and architectural dimensions $(C A A R C H)$, of which the former has the largest impact on sales prices. The higher survey respondents rated the cleanliness, safety and social characteristics (atmospheric dimension) and architectural features and quality (architectural dimension) of a restaurant, the higher was the sales price of that particular restaurant. The authenticity dimension of curb appeal, on the other hand, fails to impact asset pricing as suggested by the insignificant coefficient on $C A A U T H$. The rho for all models indicates significant spatial autocorrelation of error terms while the authenticity dimension model also suffers from significant spatial autocorrelation of sales prices (lambda), which supports the use of the GS2SLS methodology as opposed to OLS regression. 
To assess the robustness of our findings, we rerun our model in Equation 1 with the California GDP, which limits our dataset to the period of 1989 to 2013 . The results are presented in Table 5 and are in line with our previous results in Table 4. Curb appeal has a significantly positive impact on sales prices, driven by the atmospheric and architectural component.

\section{[Insert Table 4]}

\section{[Insert Table 5]}

The identified positive relationship between curb appeal and the value of a restaurant is based on the assumption that the more appealing the exterior of a building, the more likely are customers to eat at a particular restaurant. This corresponds to previous marketing studies establishing a relationship between the interior appeal of a store and customer patronage decisions (e.g. Baker, Levy and Grewal, 1992). To test this assumption, we ask survey respondents to provide their opinion to the statement "I would eat at this restaurant." after rating the exterior of a particular restaurant in our sample. Analogously, to other survey items respondents answered based on a Likert-scale ranging from 1 (strongly disagree) to 5 (strongly agree).

Table 6 presents the results of our assumption check. The atmospheric dimension of curb appeal has the highest correlation with the decision of a rater to eat at a particular restaurant, followed by the architectural dimension. While the authenticity dimension has a significantly positive correlation with the decision of raters to eat at a restaurant, it is noticeably lower than the correlations of the other 
two variables. Overall, the assumption check suggests that the curb appeal of a restaurant positively affects customer behavior in form of patronage decisions, which in turn is expected to impact sales and the value of the respective property.

Our results complement previous studies that show the effect of architectural and atmospheric features of store interior on consumer behavior (e.g. Baker, Levy and Grewal, 1992), by providing evidence that the exterior of a store also has an impact on consumer behavior and patronage decisions. This in turn explains our findings for restaurant sales prices. The greater attractiveness of a store, based on architectural and atmospheric attributes, is likely to increase customer patronage and consequently its income potential, rental rates, in line with the findings of Vandell and Lane (1989) for office buildings, and subsequently sales price.

\section{[Insert Table 6]}

\section{Conclusion and Implications}

Despite its importance to real estate developers, brokers and retailers, curb appeal and its impact on property values have been largely neglected in the real estate literature. The study represents a starting point to further investigations into this concept by firstly developing a curb appeal measurement instrument. Our findings suggest that curb appeal is a three-dimensional concept. In particular, curb appeal can be measured based on the atmosphere, architecture and authenticity of a building. Shopping center managers, developers and retailers alike may use our sentiment measure as a starting point to measure the curb appeal of their facilities and modify our instrument to adapt it to their needs. 
Future studies may employ our measurement instrument as a basis for identifying additional components of curb appeal, particularly with regard to the neighborhood of a store. Most retail stores do not exist in isolation and the surrounding stores and other neighborhood features may also contribute to the curb appeal of a store. Additionally, future studies may modify and apply our curb appeal measure in the context of other property types such as office or apartment, for example, to investigate other research questions such as the impact of curb appeal on residential tenancy decisions or employee satisfaction.

Secondly, our study shows that curb appeal, in particular the atmospheric and architectural dimensions, have a significantly positive impact on sales prices of restaurants. Thus, we provide evidence that curb appeal is an important predictor of property values, predominantly as it influences consumer patronage decisions as suggested by our assumption check. These findings have important implications for real estate developers, property managers and retailers. Architectural features such as color, construction materials or design have to be appropriately chosen for the experience a shopping center or retail facility is trying to create. Future studies may investigate whether consumer preference for certain architectural styles differ regionally and whether these difference lead to changes in the effect of the architectural curb appeal component on sales price. One of the interesting findings of our study is that the atmospheric dimension of curb appeal includes a social factor and aspects such as cleanliness, safety and maintenance. Additional research into the social component of shopping as it relates to curb appeal is needed to provide more insights into this dimension. 
Furthermore, future real estate studies may investigate whether the positive relationship between curb appeal as a multi-dimensional concept and sales prices holds for other property types such as apartments or office.

Lastly, our study contributes to the hedonic pricing model literature by showing that curb appeal is not only correlated with sales prices, but also with observable property attributes commonly included in hedonic pricing models. This provides support for the concern of Bajari et al. (2010) that the exclusion of difficult to observable property features such as curb appeal in hedonic pricing models leads to biased OLS estimates. Future studies may investigate potential biases and different curb appeal proxies in more detail. 


\section{References}

Bajari, P., Cooley, J., Kim, K.I. and Timmins, C. 2010. A Theory-Based Approach to Hedonic Price Regressions with Time-Varying Unobserved Product Attributes: The Price of Pollution, NBER Working Paper 15724, http://www.nber.org/papers/w15724.

Baker, J., Grewal, D. and Parasuraman, A. 1994. The Influence of Store Environment on Quality Inferences and Store Image. Journal of the Academy of Marketing Science, 22:4, 328-339.

Baker, J., Levy, M. and Grewal, D. 1992. An Experimental Approach to Making Retail Store Environmental Decisions. Journal of Retailing, 68:4, 445-460.

Basu, S. and Thibodeau, T.G. 1998. Analysis of Spatial Autocorrelation in House Prices. Journal of Real Estate Finance and Economics, 17:1, 61-85.

Bentler, P.M. 1990. Comparative fit indexes in structural models. Psychological Bulletin, 107:238- 246.

Browne, M.W. and Cudeck, R. 1993. Alternative ways of assessing model fit. In K. A. Bollen \& J. S. Long (Eds.), Testing structural equation models (pp. 136162). London: Sage.

Clauretie, T.M. and Daneshvary, N. 2009. Estimating the House Foreclosure Discount Corrected for Spatial Price Interdependence and Endogeneity of Marketing Time. Real Estate Economics, 37:1, 43-67.

Conway, D., Li, C.Q., Wolch, J., Kahle, C. and Jerrett, M. 2008. A Spatial Autocorrelation Approach for Examining the Effects of Urban Greenspace on Residential Property Values. Journal of Real Estate Finance and Economics, 41:150-169.

Donovan, G.H. and Butry, D.T. 2010. Trees in the City: Valuing Street Trees in Portland, Oregon. Landscape and Urban Planning, 94:77-83.

Dubin, R.A. 1998. Spatial Autocorrelation: A Primer. Journal of Housing Economics, 7:304-327.

Ford J.K., MacCallum R.C. and Tait, M. 1986. The application of exploratory factor analysis in applied psychology: A critical review and analysis. Personnel Psychology, 39:291-314.

Freybote, J., Sun, H. and Yang, X. 2014. The Impact of LEED Neighborhood Certification on Condo Prices. Real Estate Economics, forthcoming. 
Grewal, D., Baker, J., Levy, M. and Voss, G.B. 2003. The Effects of Wait Expectations and Store Atmosphere Evaluations on Patronage Intentions in Service-Intensive Retail Stores. Journal of Retailing, 79:259-268.

Grossbart, S., Hampton, R., Rammohan, B. and Lapidus, R.S. 1990. Environmental Dispositions and Customer Response to Store Atmospherics. Journal of Business Research, 21:225-241.

Hinkin, T.R. 1998. A brief tutorial on the development of measures for use in survey questionnaires. Organizational Research Methods, 1:104-121.

$\mathrm{Hu}$, L. and Bentler, P.M. 1999. Cutoff criteria for fit indexes in covariance structure analysis: Conventional criteria versus new alternatives. Structural Equation Modeling, 6: 1-55.

Jöreskog, K.G. and Sörbom, D. 1996. LISREL 8: User's reference guide. Chicago: Scientific.

Kelejian, H.H. and Prucha, I.R. 1998. A Generalized Spatial Two-Stage Least Squares Procedure for Estimating a Spatial Autoregressive Model with Autoregressive Disturbances. Journal of Real Estate Finance and Economics, $17: 1,99-121$.

Kelloway K.E. 1995. Structural equation modeling in perspective. Journal of Organizational Behavior, 7:215-224.

Mattila, A.S. and Wirtz, J. 2001. Congruency of Scent and Music as a Driver of In-Store Evaluations and Behavior. Journal of Retailing, 77:273-289.

Muthén, L.K. and Muthén, B.O. 1998-2012. Mplus User's Guide (7th ed.). Los Angeles, CA: Muthén \& Muthén.

Nunnally, J.C. 1978. Psychometric theory. New York: McGraw-Hill.

Pace, R.K., Barry, R. and Sirmans, C.F. 1998. Spatial Statistics and Real Estate. Journal of Real Estate Finance and Economics, 17:1, 15-33.

Seiler, M.J., Madhavan, P. and Liechty, M. 2012. Toward an Understanding of Real Estate Homebuyer Internet Search Behavior: An Application of Ocular Tracking Technology. Journal of Real Estate Research, 34:2, 211-241.

Sun, H., Tu, Y. and Yu, S.-M. 2005. A Spatio-Temporal Autoregressive Model for Multi-Unit Residential Market Analysis. Journal of Real Estate Finance and Economics, 31:2, 155-187. 
Turley, L.W. and Milliman, R.E. 2000. Atmospheric Effects on Shopping Behavior: A Review of the Experimental Evidence. Journal of Business Research, 49:193-211.

Vandell, K.D. and Lane, J.S. 1989. The Economics of Architecture and Urban Design: Some Preliminary Findings. Real Estate Economics, 17:2, 235-260. 


\begin{tabular}{|c|c|}
\hline Survey Item & $\begin{array}{l}\text { CA Dimension } \\
\text { (Based on CFA) }\end{array}$ \\
\hline $\begin{array}{l}\text { Cleanliness, safety, and maintenance: } \\
\text { - Has well maintained landscaping. } \\
\text { - } \text { Appears to be in a safe and secure area. } \\
\text { - Has a clean appearance. } \\
\text { - Has a pedestrian area that is well taken care of. } \\
\text { Social: } \\
\text { - Appears to be a relaxing place to eat. } \\
\text { - Appears vibrant. } \\
\text { - Seems inviting. } \\
\text { - Is a nice place to take a friend. } \\
\text { - Seems like a great place for people to get together. }\end{array}$ & $\begin{array}{l}\text { CAATM } \\
\text { CAATM } \\
\text { CAATM } \\
\text { CAATM } \\
\text { CAATM }\end{array}$ \\
\hline $\begin{array}{l}\text { Signage and Architectural Features: } \\
\text { - Has appealing exterior signage. } \\
\text { - Is located in a building that is architecturally appealing. } \\
\text { - Is located in a building that is an attractive color. } \\
\text { - Is stylishly designed. } \\
\text { - Has interesting architectural features. } \\
\text { - Is located in a building made of high quality material. }\end{array}$ & $\begin{array}{l}\text { Eliminated } \\
\text { CAARCH } \\
C A A R C H \\
C A A R C H \\
C A A R C H \\
C A A R C H \\
\end{array}$ \\
\hline $\begin{array}{l}\text { Authenticity: } \\
\text { - Appears to be authentic. } \\
\text { - Seems unique. } \\
\text { - Seems to have its own special charm. } \\
\text { - Doesn't have a fake or "plastic" appearance. }\end{array}$ & $\begin{array}{l}\text { CAAUTH } \\
\text { CAAUTH } \\
\text { CAAUTH } \\
\text { CAAUTH } \\
\end{array}$ \\
\hline \multicolumn{2}{|c|}{$\begin{array}{l}\text { Note: This table presents the survey instrument for curb appeal developed from retail real estate } \\
\text { expert interviews and previous studies, and used to measure the curb appeal of hospitality retail } \\
\text { properties (restaurants). Curb appeal dimensions were determined based on a confirmatory } \\
\text { factor analysis (CFA). CAATM represents the atmosphere dimension of curb appeal. CAARCH } \\
\text { represents the architectural dimension of curb appeal. CAAUTH represents the authenticity } \\
\text { dimension of curb appeal. }\end{array}$} \\
\hline
\end{tabular}




\begin{tabular}{|c|c|c|c|c|c|}
\hline \multicolumn{6}{|c|}{ Table 2: Descriptive Statistics } \\
\hline \multirow[b]{2}{*}{ САTOT } & \multirow{2}{*}{$\begin{array}{l}\text { Mean } \\
10.38\end{array}$} & \multirow{2}{*}{$\begin{array}{l}\text { Median } \\
10.48\end{array}$} & \multirow{2}{*}{$\begin{array}{l}\text { Standard } \\
\text { Deviation }\end{array}$} & \multirow{2}{*}{$\begin{array}{l}\text { Minimum } \\
4.76\end{array}$} & \multirow{2}{*}{$\begin{array}{l}\text { Maximum } \\
14.58\end{array}$} \\
\hline & & & & & \\
\hline CAATM & 3.66 & 3.73 & 0.55 & 1.89 & 4.89 \\
\hline CAARCH & 3.19 & 3.27 & 0.70 & 1.2 & 4.86 \\
\hline CAAUTH & 3.54 & 3.58 & 0.50 & 1.67 & 4.83 \\
\hline Age & 54.92 & 54 & 22.91 & 3 & 119 \\
\hline $\begin{array}{l}\text { Building } \\
\text { Size }\end{array}$ & $4,876.14$ & 3,782 & $5,241.61$ & 616 & 54,474 \\
\hline Land Area & 0.43 & 0.25 & 0.53 & 0.02 & 4.45 \\
\hline RF & 2.85 & 3.22 & 2.31 & 0.03 & 8.39 \\
\hline SNP & 0.01 & 0.01 & 0.01 & -0.04 & 0.02 \\
\hline UNEMP & 7.33 & 6.8 & 2.07 & 4.92 & 12.14 \\
\hline \multicolumn{6}{|c|}{$\begin{array}{l}\text { Note: This table presents the descriptive statistics for } 189 \text { restaurant transactions in Los } \\
\text { Angeles and San Diego, CA over the period of } 1989 \text { to 2014. CAATM represents the } \\
\text { atmosphere dimension of curb appeal and is based on the average rating of a picture of } \\
\text { the respective subject property by survey respondents. } 5 \text { represents the highest rating, } 1 \\
\text { the lowest. CAARCH represents the architectural dimension of curb appeal and is based } \\
\text { on the average rating of a property's picture in the survey. CAAUTH represents the } \\
\text { authenticity dimension of curb appeal and is based on the average rating of a property's } \\
\text { picture in the survey. CATOT is the sum of CAATM, CAARCH and CAAUTH for a } \\
\text { property. Age is the age of a property at the time of sale. Building Size represents the } \\
\text { building size in square feet. Land Area represents the land area in acres. RF is the risk } \\
\text { free rate based on the average annual yield of a 3-month treasury bill. SNP represent the } \\
\text { annual return on the S\&P5OO index. UNEMP is the annual unemployment rate for the } \\
\text { State of California. }\end{array}$} \\
\hline
\end{tabular}




\begin{tabular}{|c|c|c|c|c|c|}
\hline \multirow{2}{*}{\multicolumn{6}{|c|}{ Table 3: Correlations }} \\
\hline \multicolumn{3}{|c|}{ Panel A: Curb Appeal Dimensions and Dependent Variable } & & & \\
\hline \multirow[b]{3}{*}{ Sales Price } & \multirow{2}{*}{$\begin{array}{l}\text { Sales } \\
\text { Price }\end{array}$} & \multirow[t]{2}{*}{ CATOT } & \multirow[t]{2}{*}{ CAATM } & \multirow{2}{*}{ CAARCH } & \multirow[t]{2}{*}{ CAAUTH } \\
\hline & & & & & \\
\hline & \multicolumn{3}{|l|}{1.00} & & \multirow[b]{5}{*}{1.00} \\
\hline CATOT & $0.30 * * *$ & \multicolumn{2}{|l|}{1.00} & & \\
\hline CAATM & $0.21 * * *$ & \multicolumn{2}{|l|}{$0.91 * * *$} & & \\
\hline CAARCH & $0.25 * * *$ & $0.95 * * *$ & $0.84 * * *$ & 1.00 & \\
\hline CAAUTH & $0.13 *$ & $0.82 * * *$ & $0.59 * * *$ & $0.66 * * *$ & \\
\hline \multicolumn{6}{|c|}{ Panel B: Curb Appeal Dimensions and Observable Predictors } \\
\hline \multirow[b]{2}{*}{ CATOT } & Age & \multicolumn{2}{|c|}{ Building Size } & Land Area & \\
\hline & -0.05 & \multicolumn{2}{|c|}{$0.23 * * *$} & $0.18 * *$ & \\
\hline CAATM & $-0.17 * *$ & \multicolumn{2}{|c|}{$0.22 * * *$} & $0.22 * * *$ & \\
\hline CAARCH & -0.07 & \multicolumn{2}{|c|}{$0.28 * * *$} & $0.24 * * *$ & \\
\hline CAAUTH & $0.13 *$ & \multicolumn{2}{|c|}{0.08} & -0.01 & \\
\hline \multicolumn{6}{|c|}{$\begin{array}{l}\text { Note: This table presents the pair-wise correlations between curb appeal dimensions, } \\
\text { dependent variable and independent variables. CAATM represents the atmosphere } \\
\text { dimension of curb appeal and is based on the average rating of a picture of the respective } \\
\text { subject property by survey respondents. } 5 \text { represents the highest rating, } 1 \text { the lowest. } \\
\text { CAARCH represents the architectural dimension of curb appeal and is based on the } \\
\text { average rating of a property's picture in the survey. CAAUTH represents the authenticity } \\
\text { dimension of curb appeal and is based on the average rating of a property's picture in } \\
\text { the survey. CATOT is the sum of CAATM, CAARCH and CAAUTH for a property. Age is } \\
\text { the age of a property at the time of sale. Building Size represents the building size in } \\
\text { square feet. Land Area represents the land area in acres. '***', '**' and '*' denotes } \\
\text { significance at the 1\%, 5\% and } 10 \% \text { level respectively. }\end{array}$} \\
\hline
\end{tabular}




\begin{tabular}{|c|c|c|c|c|c|c|c|c|}
\hline \multicolumn{9}{|c|}{ Table 4: GS2SLS Results } \\
\hline \multirow[b]{2}{*}{ CATOT } & \multicolumn{2}{|c|}{$\begin{array}{l}\text { Total Curb Appeal } \\
\text { Coefficient }\end{array}$} & \multicolumn{2}{|c|}{$\begin{array}{l}\text { Atmospheric Dimension } \\
\text { Coefficient }\end{array}$} & \multicolumn{2}{|c|}{$\begin{array}{l}\text { Architectural Dimension } \\
\text { Coefficient }\end{array}$} & \multicolumn{2}{|c|}{$\begin{array}{l}\text { Authenticity Dimension } \\
\text { Coefficient }\end{array}$} \\
\hline & $0.08(2.41)$ & $* *$ & & & & & & \\
\hline CAATM & & & $0.28(2.89)$ & $* * *$ & & & & \\
\hline CAARCH & & & & & $0.19(2.58)$ & $* * *$ & & \\
\hline CAAUTH & & & & & & & $0.09(0.92)$ & \\
\hline Age & $0.00(0.10)$ & & $0.03(0.30)$ & & $0.01(0.15)$ & & $-0.00(-0.22)$ & \\
\hline $\mathrm{Age}^{2}$ & $-0.00(-0.27)$ & & $-0.00(-0.39)$ & & $-0.00(-0.31)$ & & $-0.00(-0.01)$ & \\
\hline Building Size & $0.06(4.34)$ & $* * *$ & $0.06(4.38)$ & $* * *$ & $0.06(4.27)$ & $* * *$ & $0.06(4.50)$ & $* * *$ \\
\hline Land Area & $0.13(0.93)$ & & $0.12(0.86)$ & & $0.12(0.84)$ & & $0.15(1.03)$ & \\
\hline $\mathrm{RF}$ & $-0.18(-6.59)$ & $* * *$ & $-0.18(-6.59)$ & $* * *$ & $-0.18(-6.61)$ & $* * *$ & $-0.18(-6.55)$ & $* * *$ \\
\hline UNEMP & $-0.09(-3.14)$ & $* * *$ & $-0.09(-3.14)$ & $* * *$ & $-0.10(-3.21)$ & $* * *$ & $-0.09(-3.00)$ & $* * *$ \\
\hline SNP & $-6.32(-1.70)$ & $*$ & $-6.62(-1.83)$ & $*$ & $-6.11(-1.65)$ & $*$ & $-6.57(-1.75)$ & $*$ \\
\hline Lambda & $0.00(1.63)$ & & $0.00(1.06)$ & & $0.00(1.54)$ & & $0.00(1.65)$ & $*$ \\
\hline Rho & $0.00(5.20)$ & $* * *$ & $0.00(3.43)$ & $* * *$ & $0.00(4.84)$ & $* * *$ & $0.00(4.71)$ & $* * *$ \\
\hline \multicolumn{9}{|c|}{$\begin{array}{l}\text { Note: This table presents the GS2SLS results for } 189 \text { restaurant transactions in Los Angeles and San Diego, CA over the period } \\
\text { of } 1989 \text { to 2014. CAATM represents the atmosphere dimension of curb appeal and is based on the average rating of a picture of } \\
\text { the respective subject property by survey respondents. } 5 \text { represents the highest rating, } 1 \text { the lowest. CAARCH represents the } \\
\text { architectural dimension of curb appeal and is based on the average rating of a property's picture in the survey. CAAUTH } \\
\text { represents the authenticity dimension of curb appeal and is based on the average rating of a property's picture in the survey. } \\
\text { CATOT is the sum of CAATM, CAARCH and CAAUTH for a property. Age is the age of a property at the time of sale. Building } \\
\text { Size represents the building size in square feet. Land Area represents the land area in acres. RF is the risk free rate based on the } \\
\text { average annual yield of a 3-month treasury bill. SNP represent the annual return on the S\&P5OO index. UNEMP is the annual } \\
\text { unemployment rate for the State of California. Z-values are presented in brackets. '***', '**' and '*' denotes significance at the } \\
1 \%, 5 \% \text { and } 10 \% \text { level respectively. }\end{array}$} \\
\hline
\end{tabular}




\begin{tabular}{|c|c|c|c|c|c|c|c|c|}
\hline \multirow[b]{2}{*}{ CATOT } & \multicolumn{2}{|c|}{$\begin{array}{l}\text { Total Curb Appeal } \\
\text { Coefficient }\end{array}$} & \multicolumn{2}{|c|}{$\begin{array}{l}\text { Atmospheric Dimension } \\
\text { Coefficient }\end{array}$} & \multicolumn{2}{|c|}{$\begin{array}{l}\text { Architectural Dimension } \\
\text { Coefficient }\end{array}$} & \multicolumn{2}{|c|}{$\begin{array}{l}\text { Authenticity Dimension } \\
\text { Coefficient }\end{array}$} \\
\hline & $0.08(2.47)$ & $* *$ & & & & & & \\
\hline CAATM & & & $0.23(2.52)$ & $* *$ & & & & \\
\hline CAARCH & & & & & $0.19(2.66)$ & $* * *$ & & \\
\hline CAAUTH & & & & & & & $0.12(1.25)$ & \\
\hline Age & $-0.01(-0.71)$ & & $-0.01(0.65)$ & & $-0.01(-0.67)$ & & $-0.01(-1.04)$ & \\
\hline $\mathrm{Age}^{2}$ & $0.00(0.45)$ & & $0.00(0.46)$ & & $0.00(0.42)$ & & $0.00(0.73)$ & \\
\hline Building Size & $0.06(4.69)$ & $* * *$ & $0.06(4.71)$ & $* * *$ & $0.06(4.60)$ & $* * *$ & $0.06(4.77)$ & $* * *$ \\
\hline Land Area & $0.07(0.54)$ & & $0.08(0.62)$ & & $0.07(0.52)$ & & $0.09(0.70)$ & \\
\hline $\mathrm{RF}$ & $0.00(0.05)$ & & $-0.00(-0.01)$ & & $0.00(0.05)$ & & $-0.00(-0.00)$ & \\
\hline UNEMP & $0.00(0.14)$ & & $0.00(0.10)$ & & $0.00(0.08)$ & & $0.01(0.23)$ & \\
\hline GDP & $0.01(6.46)$ & $* * *$ & $0.09(6.39)$ & $* * *$ & $0.01(6.45)$ & $* * *$ & $0.01(6.55)$ & $* * *$ \\
\hline SNP & $-6.34(-1.85)$ & $*$ & $-6.49(-1.91)$ & $*$ & $-6.22(-1.83)$ & $*$ & $-6.35(-1.83)$ & $*$ \\
\hline Lambda & $0.00(2.05)$ & $* *$ & $0.00(2.51)$ & $* *$ & $0.00(2.25)$ & $* *$ & $0.00(2.10)$ & $* *$ \\
\hline Rho & $0.00(4.26)$ & $* * *$ & $0.00(2.86)$ & $* * *$ & $0.00(4.17)$ & $* * *$ & $0.00(4.46)$ & $* * *$ \\
\hline \multicolumn{9}{|c|}{$\begin{array}{l}\text { Note: This table presents the GS2SLS results for } 174 \text { restaurant transactions in Los Angeles and San Diego, CA over the period } \\
\text { of } 1989 \text { to 2013. CAATM represents the atmosphere dimension of curb appeal and is based on the average rating of a picture of } \\
\text { the respective subject property by survey respondents. } 5 \text { represents the highest rating, } 1 \text { the lowest. CAARCH represents the } \\
\text { architectural dimension of curb appeal and is based on the average rating of a property's picture in the survey. CAAUTH } \\
\text { represents the authenticity dimension of curb appeal and is based on the average rating of a property's picture in the survey. } \\
\text { CATOT is the sum of CAATM, CAARCH and CAAUTH for a property. Age is the age of a property at the time of sale. Building } \\
\text { Size represents the building size in square feet. Land Area represents the land area in acres. RF is the risk free rate based on the } \\
\text { average annual yield of a 3-month treasury bill. GDP is the annual gross domestic product for the State of California. SNP } \\
\text { represent the annual return on the S\&P500 index. UNEMP is the annual unemployment rate for the State of California. Z-values } \\
\text { are presented in brackets. '***', '**' and '*' denotes significance at the 1\%, 5\% and } 10 \% \text { level respectively. }\end{array}$} \\
\hline
\end{tabular}




\begin{tabular}{|c|c|}
\hline \multicolumn{2}{|r|}{ mption Check: Curb Appeal Dimensions and Dining Decision } \\
\hline & DIN \\
\hline CATOT & $0.74 *$ \\
\hline CAATM & $0.86 *$ \\
\hline CAARCH & $0.80 * * *$ \\
\hline CAAUTH & $0.54 * * *$ \\
\hline \multicolumn{2}{|c|}{$\begin{array}{l}\text { Note: This table presents the pair-wise correlations between curb appeal dimensions and an } \\
\text { assumption check variable. CAATM represents the atmosphere dimension of curb appeal and is } \\
\text { based on the average rating of a picture of the respective subject property by survey respondents. } \\
5 \text { represents the highest rating, I the lowest. CAARCH represents the architectural dimension of } \\
\text { curb appeal and is based on the average rating of a property's picture in the survey. CAAUTH } \\
\text { represents the authenticity dimension of curb appeal and is based on the average rating of a } \\
\text { property's picture in the survey. CATOT is the sum of CAATM, CAARCH and CAAUTH for a } \\
\text { property. DIN is based on the survey item "I would eat at this restaurant.", which survey } \\
\text { respondents answered on a Likert-scale from } 1 \text { (strongly disagree) to } 5 \text { (strongly agree). '***' } \\
\text { denotes significance at the 1\% level. }\end{array}$} \\
\hline
\end{tabular}

